\title{
Legal Protection of Minority Shareholders under Corporate Governance Process
}

\author{
Suresh Kumar M V ${ }^{1}$, Lakshmana Rao $\mathbf{C H}^{2}$ \\ ${ }^{1}$ LAW, koneru Lakshmaiah Education Foundation, Green Fields, GUNTUR, 522502, Andhra Pradesh, India \\ Orcid I'd: 0000-0003-2937-3209 and Publons I'd: ABF-8905-2020 \\ ${ }^{2}$ Koneru Lakshmaiah Education Foundation, Green Fields, GUNTUR, 522502, Andhra Pradesh, India
}

\begin{abstract}
In recent days, most of the corporate are failing in managing business effectively and the major cause for this is conflicts between majority and minority shareholders of the company which lead to direct or indirect destruction of business at the end. Even though, there are certain laws and provisions made for the sake of minority shareholders, those are enforced well and needs to make them as utmost safeguards to minority shareholders.

In this paper, we will discuss the issues for conflict including rights of minority shareholders as well as roles and responsibilities of shareholders by analyzing possible solution for conflicts between majority and minority shareholder.
\end{abstract}

KEYWORDS: Corporate Governance, Minority Shareholders, Majority Shareholders, Rights of Minority Shareholders, Duties of Minority Shareholders

\section{INTRODUCTION}

The Companies Act 2013 introduced significant changes in the provisions by introduction of new concepts and definitions as detailed below

- One-Person

- Small Company

- Dormant Company

- Independent Director

- Corporate social responsibility-based Governance, including E-Management, with effective Compliance \& Enforcement Procedures

- Introduced new concepts such as Disclosure Norms, by Auditors

- Companies Mergers \& Acquisitions.

- Class Action Suits

- Registered Valuers

One-person company: One of the innovative concept of 2013 Companies Act is introduction of 'one-person company' (OPC) from other alternatives including a public and private. An OPC operating as a company with only one person on board who is running the business overall [Section 3(1)].

Small company: Small company can be defined as a company which has Paid-up share capital not exceeding 50 lakhs, and Turnover not exceeding 2 crores as per its last profit-andloss account or such higher amount as may be prescribed which is limited to five crores and such higher amount which shall not exceed 20 Crores

Dormant company: The Companies Act 2013 gave a new concept of inactive company as one which is not having significant accounting transactions even after certain period of time after its incorporation with an aim of business in a given financial year and which inactive over a period of time upon which one can apply to the ROC in a prescribed format as laid by companies act U/S 455

Independent Director: In the Companies act 2013 term' Independent Director' has been defined as a person other than a Whole time Director (or) a Managing Director (or) a Nominee Director with a set of rules and regulations to be followed and are in line with requirements as per listed company's agreement U/s 2 and Related. 


\section{International Journal of Current Science Research and Review}

ISSN: 2581-8341

Volume 04 Issue 04 April 2021

DOI: 10.47191/ijcsrr/V4-i4-09, Impact Factor: 5.825

IJCSRR@ 2021

www.ijcsrr.org

The New Companies Act 2013 took a step further to mandates the appointment of an internal auditor who is a qualified chartered accountant or a cost accountant, or such other professional as may be decided by the Board of directors to examine the records of the company and conduct internal audit of the company.

\subsection{Regulators}

The latest act has given consent for constitution of National Company Law Tribunal (NCLT) \& National Company Law Appellate Tribunal.

a) National Company Law Tribunal (Tribunal or NCLT): In accordance with the Apex Court Judgment on 11 May 2010 , the companies act under section 407 to 434 has laid down the composition and powers of both

b) The central government U/S 408 of the companies act 2013 has constituted the NCLT on 01-06-2016

c) In the first phase eleven benches has been set up in the NCLT which consolidates the corporate jurisdiction of the following

(i) Company Law Board

(ii) Board for Industrial and financial reconstruction

(iii) Industrial financial Reconstruction appellate authority (iv) Jurisdiction and powers relating to winding up and restructuring.

d) NCLAT under section 410 constituting of a chairperson not exceeding eleven members for hearing appeals against the orders of the tribunal..

\subsection{Capital in reference to Minority and Majority Shareholder}

The Companies act 2013 introduced some key changes in relation to share capital and debentures.

(i) Regarding section 90 of the 1956 Act latest Act does not give any cognizance to the existing requirement of Act that provided some saving grace to private companies in comparison to the Public companies and said that both have equal applicability.

(ii) Regarding Corporate governance Companies Act 2013 has set out some norms by requiring disclosure of

- Directors \& KMP Concern or Interest in business including details of Relatives of Such person involved in business and their details in regard to Payment of remuneration and share holding pattern.

- $\quad$ The Reduction in Threshold of Disclosure From $20 \%$ To $2 \%$.

- $\quad$ 'Key Managerial Personnel' Includes the following as per Companies act 2013

- $\quad$ The CEO/MD of the concern,

- $\quad$ Manager including CFO \& Company Secretary.

According to the instructions of the MCA a return in respect of change in shares held by the board including promoters along with top 10 shareholders has to file a return of change in respect of the companies listed on stock exchange and also observe secretarial standards as specified by ICSI on annual basis by making the disclosures with respect to general and board meetings held by the companies.

\section{CORPORATE GOVERNANCE}

It is a system that defines the procedures to be followed by organizations in the way to direct and control the organizations.

The main agenda of corporate governance is to maximize the wealth of shareholders by monitoring and controlling the functions of management.

Three main focusing issues arising in corporate governance in our paper are conflicts between

1) Shareholders and Managers,

2) Controlling (Majority) shareholders and outside (Minority) shareholders and

3) Shareholders and bond holders. Conflicts between majority and minority shareholders' effects the corporate at management level itself. Among these, the struggle between Minority shareholders (the principle) and Majority shareholders (the agents) is a key agency problem.

It is an evident fact that the majority shareholders have control and governance the corporate and so instinctively they are in the expedient position over the minority shareholders. But, it is very difficult to run the business as well as focusing on other issues to management if this kind of issues raised. A good relationship and understanding between minority and majority shareholders will help to growth of business. 


\section{International Journal of Current Science Research and Review}

ISSN: 2581-8341

Volume 04 Issue 04 April 2021

DOI: 10.47191/ijcsrr/V4-i4-09, Impact Factor: 5.825

IJCSRR@ 2021

Www.ijcsrr.org

\subsection{Stakeholders}

The responsibility, role and challenges of the various stakeholders is detailed below

1. Share holders who main interest is value maximization, profitability, liquidity-growthmarket price

2. Government whose main interest is tax, employment, true reporting, diversity,

3. Employees whose main aim is benefit maximization, quality of work

4. Customers who main interest is quality, price, care

5. Creditors who main interest is liquidity, debt servicing

6. $\quad$ Competitors whose main interest is fair business

7. Community whose main interest is job, environment protection

8. Investors whose main interest is share price and corporate image.

\section{$2.2 \quad$ Board of Directors}

The Board of Directors are those who act as representatives on behalf of the company which is an artificial person with separate legal entity, and which will exist even when directors come and go in the course of business. The board of Directors are entitled to exercise such powers that may be required in the process of running the business in a lawful manner and according to the memorandum and articles of association as set out in the process of incorporation of the company.

Board of Directors are bestowed with the following powers

a) Issue securities including debentures and shares

b) Conduct all kinds of meetings chaired by one director as chairman of the meeting to conduct all regular activities that require a board resolution and adopted all such amendments and regulations by passing an ordinary resolution and special resolution as required by the company and according to company law from time to time

c) To appoint auditors and internal auditors who finalize the annual accounts of the company

d) To borrow funds and pay back the funds borrowed on behalf of the company and also buy back shares according to the articles of association.

\subsection{Employees}

The modern-day business has seen the downfall of the companies like Enron and the world Com due to non-participation of employees that gave rise to the employees becoming part of the stake holders and leading to the participation in corporate governance overall. The employees as stake holder can play a key role in progress of the company.

\subsection{Creditors}

The creditors' role in corporate governance is a vital factor for the success of the business as they lend a helping hand in giving the loans and financing of the company in the process of expansion and diversification of the business and on the whole running of the business according to the terms and conditions set out in the liability clause of the company.

\subsection{Customers}

Customer is a person who buys or hires any service of the company for some consideration to be paid to the company before or after the service is rendered and in the process of fulfillment of the obligation by the company and in accordance with rules set out in the corporate governance policy of the company. The customer is the end user of the product of the company, and he will be treated as an important asset in the corporate governance as he is the right judge in company day to day business.

\subsection{Business partners}

According to Corporate Governance business partners play an important role in the process of building the business by giving proper platform for the process of trading within the code of conduct and accordingly being a part of the day to day affairs of the company.

\subsection{Government}

In the present-day business government plays an important role in the corporate governance process by defining the legal provisions and environment in which the business must function and by influencing the managerial decision process and also in times of bankruptcy by financing the loans and by giving a helping hand in the case of sick industry when needed. 


\section{International Journal of Current Science Research and Review}

ISSN: 2581-8341

Volume 04 Issue 04 April 2021

DOI: 10.47191/ijcsrr/V4-i4-09, Impact Factor: 5.825

IJCSRR@ 2021

www.ijesrr.org

\subsection{Accountants}

In view of increasing frauds and increasing importance of corporate governance accountants play very vital role in management decisions as they have to account for the share holders who based upon the reporting of financial statements of the company decide on the investment in the business in the form of shares and securities based upon international accepted accounting policies.

\subsection{Auditors}

The stakeholders rely on the auditors for presentation of true and fair financial reports which gives an actual and accurate report of financial position of the company in which they have invested a lot of amount by way of shares. The corporate governance process let auditors to prevent occurrence of frauds and eradicating the malpractices that are present in the running of the business.

\subsection{Competitors}

The role of the competitors in business is inevitable as it leads to a relatively fair and healthy business cycle. According to the code it should be conducted without any prejudice and unlawful practices by the competitors.

\subsection{Society}

According to the corporate governance process society as a stake holder in the present-day business should be people friendly and it should be carried on the betterment of the society overall and for the welfare and wellbeing of the people living in the society.

\section{SHAREHOLDERS}

The market functions with two kinds of shareholders, viz. institutional shareholders and Individual shareholders, according to the articles of association of the company and as per law the basic rights are as follows.
a) The right to attend meetings and to vote
b) To transfer shares and receive dividend when declared and elect directors
c) The have right to shares and bonus shares when compared to others.
d) To file class action suite
e) They represent the affairs of the company in the form of independent directors.

\subsection{Minority shareholders and their Responsibilities}

The term Minority Shareholder has not been described under any law, but, it is broadly referenced as an equity shareholder who owns less than 50 percent of share in a corporate. Due to this less shareholding pattern of the minority shareholders they don't have: 1. Voting Control and 2. Management control over the company.

Under the corporate law, Minority shareholders also have several rights that are entitled to act on their own interest and not subject to fiduciary or other duties to act in the interests of majority shareholders apart from some definite conditions. Despite the fact, it is necessary to reconsider the rights and responsibilities of minority shareholders legally because of the substantial influence of majority shareholders in such instances hedge funds, index funds etc.

\subsection{Roles and Powers of Minority Shareholders}

Though Minority shareholders have minimal authority than major shareholders, they too have powers to take necessary decisions as well as control and monitor the corporate activities. Some of the roles and powers of the minority shareholders are listed here for understanding the position of minority shareholders:

- $\quad$ Checking the books and records of the company

- $\quad$ Attending shareholder meetings

- $\quad$ Addressing directors and shareholders in the meetings

- $\quad$ Making claims against any director or officer who misuse their fiduciary duties like using corporate funds to personal benefits or misleading the stakeholders/investors.

\subsection{Rights of minority shareholder}

1. Appointment of a director- : Under companies act 2013 and in corporate governance process in protection of minority shareholders they have a right to appoint a director or elect a director when $1 / 10^{\text {th }}$ of total number of such shareholders or at least $1 \mathrm{k}$ of shareholders come together with common aim. 


\section{International Journal of Current Science Research and Review}

ISSN: 2581-8341

Volume 04 Issue 04 April 2021

DOI: 10.47191/ijcsrr/V4-i4-09, Impact Factor: 5.825

IJCSRR@ 2021

WwW.ijcsrr.org

2. The directors appointed by minority shareholders are considered as independent directors with Right in decision-making process of the company.

3. Oppression and mismanagement- In Corporate governance process the minority shareholders can approach the National Company law tribunal for any oppression and mismanagement issue tha take place with regards to the shareholders rights.

4. Rights with respect to reconstruction and amalgamation - In the process of corporate governance and with respect to the law of land minority shareholders can purchase shares of any company which is going for reconstruction and amalgamation with another company by dissenting shareholders at a determined value by the registered valuer. The minority shareholders has also been given a right to make an offer to the majority shareholders to buy the shares of minority shareholders.

5. Class action suit: the minority shareholders as per the provisions of Companies Act, 2013, may file Class action suit. Rao (1956); MANOHAR (1997); Chandrachud (1981); Edwards (1950); Harbottle (1843); Miheer (1996); Tulloch (1860); Shinkar (1933); Kershaw

(2013); Wanchoo (1965)

\subsection{Reasons for conflicts between minority and majority}

Most of the majority shareholders believe that they have more rights on the company, and they can do anything. Minority shareholders will be punished in some cases because of the misuse of rights and powers of majority shareholders. Due to unethical practices of some controlling shareholders' such as fund diversion, starting other business, unauthorized party transactions, deliberate reinvest the profits gain in the business so as to negate the returns to minority shareholders, appointing the directors/employees who favouring to them even by paying high packages, overall company growth will come down. Even though there is no involvement of minority shareholders in these activities, in some cases they also to be faced problems when any issue raises. Some other problems faced by the minority shareholders are:

- Controlling shareholders always search for various methods for removing minority shareholders. Finally, squeeze-out the minority shareholders.

- Raising claims on minority shareholders through using various fiduciary duties having by majority shareholders

- In the companies, where the majority shareholders manage the board, there is very less scope for minorities because they do not have any control on running of business.

All these above, due to less powers and marketability of minorities they became worthless in the view of company. So, the majorities try to remove the minorities in all the ways.

But, to protect the interests and rights of the minority shareholders most of the countries provide various legislation s and rules.

\section{LEGAL PROTECTION TO MINORITY SHAREHOLDERS IN VARIOUS COUNTRIES}

All the countries made various laws and rules to protect the minority shareholders recently. Now, we will discuss some of the most effective measures taken in those countries and the consequences.

India: Company's Act 1956 says Sec 397 an application is made to Company Law Board for relief in cases of oppression and 398 in cases of mismanagement, to provide protection to the minority shareholders from the oppression and mismanagement of the majority.

Whereas Company's Act 2013 says that sections 241-246 provides protection against the oppression and mismanagement by the majority shareholders upon minority shareholders upon an application for relief can be made to the Tribunal in case of oppression and Mismanagement.

This is an enormous departure from the provisions of CA 1956 because the discretion which was provided to the Central Government to permit any number of shareholders to be considered as non-majority is, under the new CA 2013 been given to Tribunal and thus is likely to be exercised.

People Republic of China: In china, recently during 1994, New company law has been come into effect with the main purpose to provide legal protection for the state owned corporations into stock companies. After that, in October 2005 due to more private possession on stocks forces to made amendments in this law as it gives more protection to minority shareholders. According to this company law, while establishing a listed company it should ensure that full exercise of shareholders rights and the corporate governance make sure that the fair treatment of all shareholders especially minority shareholders and it should be facilitating the 


\section{International Journal of Current Science Research and Review}

ISSN: 2581-8341

Volume 04 Issue 04 April 2021

DOI: 10.47191/ijcsrr/V4-i4-09, Impact Factor: 5.825

IJCSRR@ 2021

Www.ijesrr.org

minority shareholders to enjoy their rights and to perform their duties based on their shareholding. And it is also clearly stated that the majority shareholders should be with good faith and not to show any authority and not to do any harm to the minority/other shareholders and company.

Belgium: In Belgium on $7^{\text {th }}$ May 1999, the New Company law has been adopted. Belgium corporate governance mainly focused on to set standards and benchmarks on corporate behaviours and structures with transparency. According to Art. 66bis(2) this law gives right to minority shareholders to institute an action against directors or other shareholders who are liable for the loss by breaching the company laws.

Brazil: Brazilian corporate governance law gives cumulative or multiple voting right to minority shareholders who have $10 \%$ of the voting capital of the enterprise as the minority shareholders can vote cumulatively for only one candidate or can distribute his votes among other candidates.

Chile: As per Chile Companies Act, 1981 minority shareholders can participate the general meetings of the companies. Article 58.3 clearly states that minority shareholders having $10 \%$ voting rights must be called for general meetings and they can also set the meeting agenda but not only indicate the points to be discussed in the meeting.

Italy: Like Chile, Italy also made a provision through Article 2367 of Civil Code as minority shareholders who possessed $20 \%$ of the company share to set items to be discussed as well as to give suggestions by attending the general meeting of the corporate. But, later the article has been modified the same as the minority shareholding limited to $10 \%$ of the company capital.

\section{SOLUTIONS FOR DIFFICULTIES FACED BY MINORITY SHAREHOLDERS}

The following measures help to resolve the issues raising towards protection of minority shareholders in the corporate:

- $\quad$ Review and if need made necessary changes in the shareholders' agreement for minority shareholders through correct disclosures

- $\quad$ Compulsory payment of dividends to minority shareholders

- $\quad$ Not to give scope for any unfair prejudicial treatments towards minority shareholders

- $\quad$ Facilitating minorities also to attend, discuss and give suggestions in general meetings

- $\quad$ Negotiation and satisfactory settlement in case of shares transferring

- $\quad$ Dilution of shareholding of minorities by giving chance to them to avail their preemption right

- Utilization of winding up action

- $\quad$ Provision of Piggy Backing where the minority shareholder be allowed buy the shares of the majority shareholder

- $\quad$ Minority and 'Minority Interest' should be specified in the substantive Law

- $\quad$ Rights in case of Oppression and Mismanagement

- $\quad$ Rights of minority shareholders during mergers/ amalgamations/ takeovers

6 POINTS TO BE NOTED

1. Shareholders are considered as owners of the company and should be given proper attention even if they hold small amount of stake or larger share in the form of share capital

2. Minority shareholders have to involve themselves in every aspect of the company and take active interest in dealing with the majority shareholders

3. Minority shareholders should protest against any misleading statement that is made by the board or any irregularities that take place in the functioning of the company

4. Minority shareholders must place their points clear when it comes to the dissolution of the company in respect of the shares held by themselves in the company and regarding the pattern of the payment after dissolution process

5. Minority share holders in the company should force equal status at the time of winding up of the company in regards to pay out of amount to the shareholders from time to time

6. Minority shareholders should be given due importance in the process of amalgamation and merger of the company with an equal (or) superior company in respected of the process adopted and in respect of the present and future strategies adopted by the company from time to time. 


\section{International Journal of Current Science Research and Review}

ISSN: 2581-8341

Volume 04 Issue 04 April 2021

DOI: 10.47191/ijcsrr/V4-i4-09, Impact Factor: 5.825

IJCSRR@ 2021

Www.ijcsrr.org

\section{CONCLUSION}

Corporate need to protect the interest of minority shareholders through the corporate governance. While the concept of corporate democracy has evolved over time, so has the nature, identity, and interests of minority shareholders. They are no longer retail investors, but institutional investors who have taken on significant shareholding positions in companies around the world. These include mutual funds, pension funds and hedge funds. While some of them are activist in nature, others are passive, although these characteristics could vary by degree

Legal systems around the world enable minority shareholders to enhance their participation in companies. Activist investors like hedge funds have utilized these developments to challenge managements in not only companies and countries with dispersed shareholding, but also in those with concentrated shareholding. While their actions could be beneficial in enhancing corporate performance by creating a market for corporate influence, activist investors have the potential to derive private benefits not shared with other shareholders. They may also suffer from conflicts of interests. Hence, there is an increasing call to subject activist shareholders to legal constraints such as the imposition of fiduciary duties, similar to that for controlling shareholders. Finally, minority shareholders should increase awareness about their rights, powers and duties in corporate and perform as per that in the corporation.

Figures

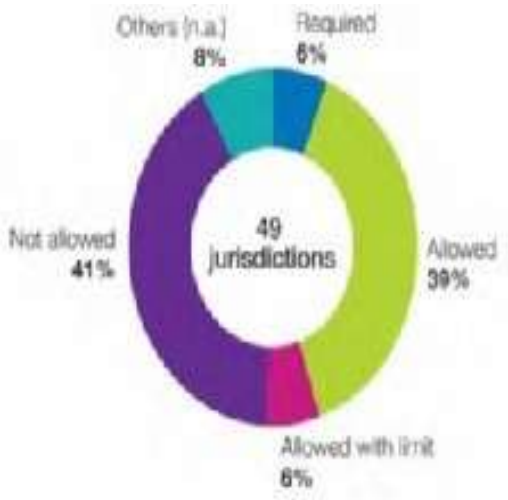

Figure 1. Cumulative voting

\section{BIBLIOGRAPHY}

“Corporate Governance (2016); Asish et al. (2016); K and G (2019); 933 (2016); By (2013) ; Book and Kumar (2011); By (2011); Rao (1956); By (2018) Ramaiya (2015) Sulalit and Act

(2013) Bajaj and Agarwal (2004); Banerjee and Chandrasekaran (1996); Berte and Means (1932); Arora et al. (2004); Balachandran (1996); 933 (1997); Balasubramanian (1988); Akoi et al. (1995); Bhagawati (1993)

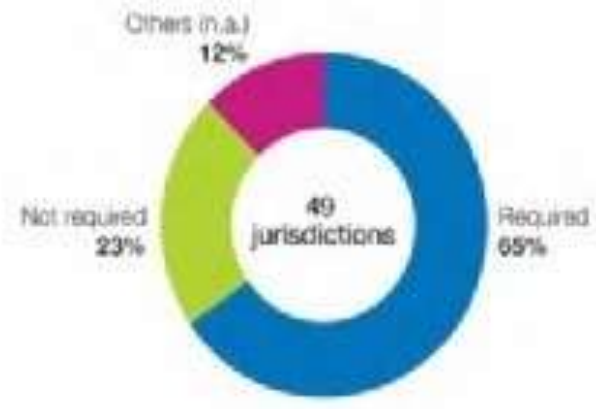

Figure 2. Majority voting requirement for board election 


\section{International Journal of Current Science Research and Review}

ISSN: 2581-8341

Volume 04 Issue 04 April 2021

DOI: 10.47191/ijesrr/V4-i4-09, Impact Factor: 5.825

IJCSRR@ 2021

www.ijesrr.org

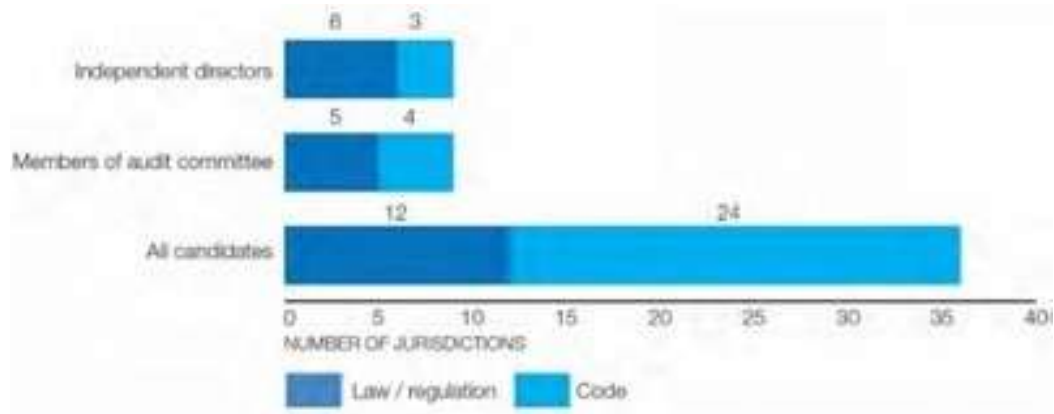

Figure 3. Qualification requirements for board member candidates

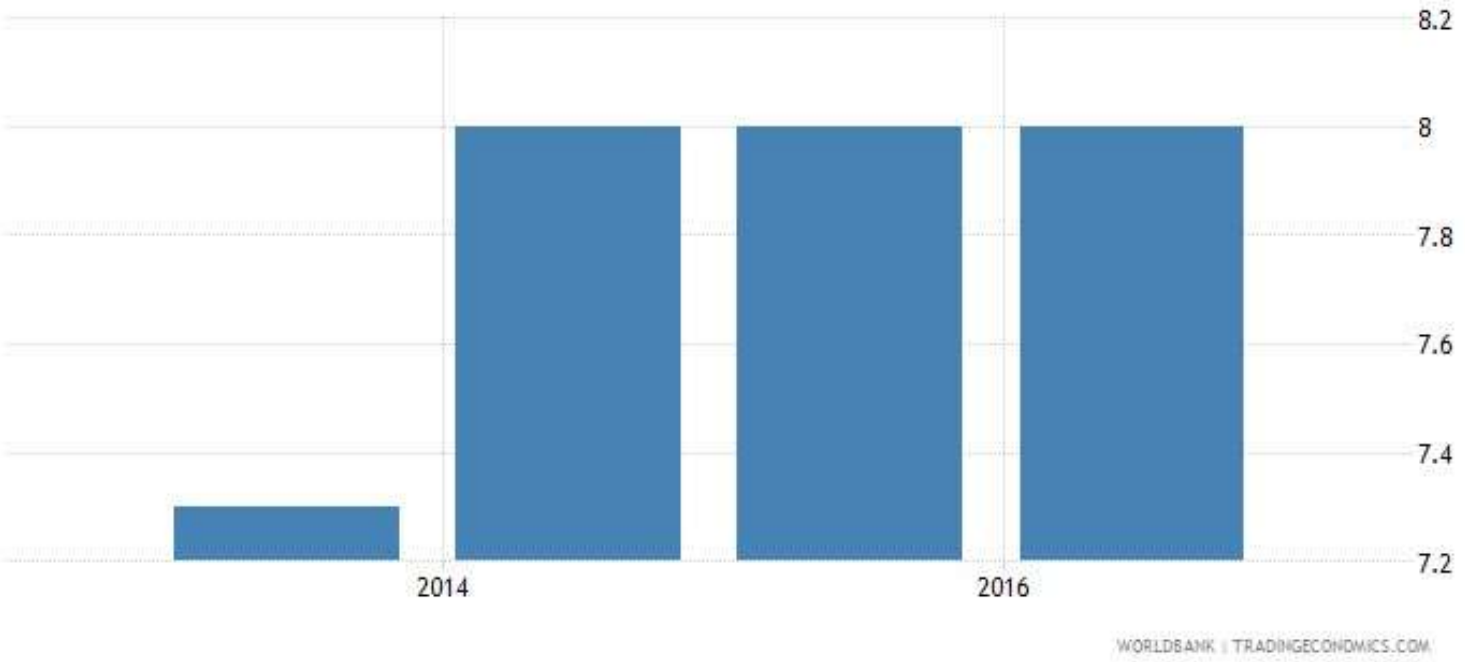

Figure 4. India-strength-of-governance-structure-index

\section{CASES REFERRED}

Kershaw (2013) Shinkar (1933) Tulloch (1860) Miheer (1996); Harbottle (1843); Edwards

(1950) Chandrachud (1981); MANOHAR (1997); Wanchoo (1965); Rao (1956)

\section{REFERENCES}

1. "Corporate Governance and Business Ethics." AIMA (1997).

2. Corporate Governance in India: An evaluation (2016).

3. Akoi, M., and H. Kim, editors. Corporate Governance in Transitional Economies: Insider Control and the Role of Banks. Washington, D.C.: The World Bank, 1995.

4. Arora, Ramesh K, and Tanjul Saxena, editors. Corporate Governance: Issues and Perspectives. Janur: Mangaldeep, 2004.

5. Asish, K, Bhattacharyya, and Book On. "Corporate Governance in India: Change and Continuity." Journal of Economic and Social Development 87 (2016).

6. Bajaj, P S and Raj Agarwal. Business Ethics: An Indian Perspective. New Delhi: Biztantra, 2004.

7. Balachandran, S 1996 Managing Ethics.

8. Balasubramanian, S. Corporate Boards and Governance. 1988.

9. Banerjee, A M and K A Chandrasekaran. Renewing Governance: Issues and Options. New Delhi: Tata McGraw Hill, 1996.

10. Berte, A A and G C Means. The Modern Corporations and Private Properties. New York: McGraw-Hill, 1932.

11. Bhagawati, J. India in Transition: Freeing the Economy. Oxford: Oxford University Press, 1993.

12. Book, T N and Kumar. "Corporate Governance: Principles and Practices.” Pearson Education India (2011). 


\section{International Journal of Current Science Research and Review}

ISSN: 2581-8341

Volume 04 Issue 04 April 2021

DOI: 10.47191/ijesrr/V4-i4-09, Impact Factor: 5.825

IJCSRR@ 2021

www.ijesrr.org

13. By, Fernando Book. "Business Ethics and Corporate Governance." Pearson Education India (2018).

14. By, Prasad K Book Corporate Governance (2011).

15. By, Tricker Book 2013 Corporate Governance: Principles, Policies and Practices.

16. Chandrachud, Y. "Needle Industries (India) v. Needle Industries Newey (India) Holding Ltd."

17. 1981 Needle Industries (India) v. Needle Industries Newey (India) Holding Ltd.

18. Governance“corporate . "By IICA.” Taxmann (2016).

19. Edwards. 1950 "Edwards V Haliwel.".

20. Harbottle, Foss V. 1843 "Foss V Harbottle.".

21. K, Viyyanna Rao and Naga Raju G. "Business Ethics and Corporate Governance." Business Ethics and Corporate Governance. Ed. and others New Delhi: Dreamtech Press, 2019 , 1-561.

22. Kershaw, D 2013 The Rule in Foss $v$ Harbottle is Dead; Long Live the Rule in Foss v Harbottle.

23. MANOHAR, MRS. SUJATA V. "Sri Ramdas Motor Transport Ltd. v. Tadi Adhinarayana Reddy and Ors." 1997 Sri Ramdas Motor Transport Ltd. v. Tadi Adhinarayana Reddy and Ors.

24. Miheer, H 1996 Mafatlal Industries Ltd.

25. Ramaiya, A. Ed. A Ramaiya et al. 18 edition. 2015.

26. Rao, Subba. 1956 "Rajahmundry Electric Supply Corporation v. A. Nageshwara Rao.”.

27. 1933 Shinkar, Bhajekar V.

28. Sulalit, A and Companies Act. Ed. and others. 2013.

29. 1860 Tulloch, Davidson V.

30. Wanchoo, K. Ed. Shanti Prasad Jain v. Kalinga Tubes Ltd. 1965.

Cite this Article: Suresh Kumar M V, Lakshmana Rao CH(2021). Legal Protection of Minority Shareholders under Corporate Governance Process. International Journal of Current Science Research and Review, 4(4), 308-316 